\title{
Aspects of the biology and morphology of Dirphia dolosa Bouvier, 1929 (Lepidoptera: Saturniidae: Hemileucinae)
}

\author{
Alexandre Specht ${ }^{1,4}$, Edegar Fronza ${ }^{2}$, Evandro Emanoel Colombi ${ }^{2}$, \\ Aline Carraro Formentini ${ }^{2} \&$ Elio Corseuil $^{3}$ \\ ${ }^{1}$ Laboratório de Entomologia, Embrapa Cerrados, Rod. BR 020, Km 18, CP 08223, \\ CEP 73310-970, Planaltina, DF, Brasil. www.cpac.embrapa.br \\ ${ }^{2}$ Instituto de Biotecnologia, Universidade de Caxias do Sul-UCS, Rua Francisco Getúlio Vargas, 1130, \\ CEP 95070-560, Caxias do Sul, RS, Brasil. www.ucs.br \\ ${ }^{3}$ Laboratório de Entomologia, Pontifícia Universidade Católica do Rio Grande do Sul - PUCRS, \\ Av. Ipiranga, 6681, CEP 90619-900, Porto Alegre, RS, Brasil \\ ${ }^{4}$ Corresponding author: Alexandre Specht, e-mail: alexandre.specht@embrapa.br
}

SPECHT, A., FRONZA, E., COLOMBI, E.E., FORMENTINI, A.C. \& CORSEUIL, E. Aspects of the biology and morphology of Dirphia dolosa Bouvier, 1929 (Lepidoptera: Saturniidae: Hemileucinae). Biota Neotrop. 12(4): http://www.biotaneotropica.org.br/v12n4/en/abstract?article+bn00212042012

Abstract: Dirphia dolosa Bouvier, 1929 is an endemic moth from southern Brazil, with available information restricted to occurrence data, natural host plant and adult morphology. This study describes bionomic peculiarities of this species, obtained from observations of larval aggregations in the field and in the laboratory. Data on all developmental stages are presented and compared with those of other Hemileucinae. D. dolos a present a facultative pupal diapause and may have two generations per year under the climatic conditions of the Rio Grande do Sul State, Brazil.

Keywords: Atlantic Forest, biodiversity conservation, development, Myrsinaceae.

SPECHT, A., FRONZA, E., COLOMBI, E.E., FORMENTINI, A.C. \& CORSEUIL, E. Aspectos da biologia e morfologia de Dirphia dolosa Bouvier, 1929 (Lepidoptera: Saturniidae: Hemileucinae). Biota Neotrop. 12(4): http://www.biotaneotropica.org.br/v12n4/pt/abstract?article+bn00212042012

Resumo: Dirphia dolosa Bouvier, 1929 é uma mariposa endêmica do Sul do Brasil, cujas informações restringem-se a dados de ocorrência, planta hospedeira natural e aspectos morfológicos dos adultos. Este estudo descreve particularidades bionômicas desta espécie, obtidas em observações de agregações de larvas no campo e em laboratório. Dados sobre todos os estágios de desenvolvimento são apresentados e comparados com os de outros hemileucíneos. D. dolosa apresenta diapausa pupal facultativa e pode apresentar duas gerações anuais nas condições climáticas do Rio Grande do Sul.

Palavras-chave: Floresta Atlântica, conservação da biodiversidade, desenvolvimento, Myrsinaceae. 


\section{Introduction}

The Hemileucinae, the most abundant and diverse subfamily of Saturniidae, includes 670 taxa belonging to 49 genera. Among these, the genus Dirphia Hübner, [1819] stands out, with its medium to large sized moths, whose larvae of most species preferentially feed on woody plants, and are urticating like the other Hemileucinae. Its species are distributed throughout most of the Neotropics, from Nicaragua to Argentina. This genus includes 40 species, of which 21 occur in Brazil, with seven endemic species (Lemaire 2002, Mielke $\&$ Moser 2007). For most species there are still no information on the biology and morphology of immature stages (Lemaire 2002).

Dirphia dolosa Bouvier, 1929 is endemic to southern Brazil, with records in Paraná, Santa Catarina and Rio Grande do Sul. This species was confused with Dirphia ursina Walker, 1855, which occurs in the central region of Colombia and northwestern Argentina, due to the great similarity of the structure and coloration of the wings (Oiticica Filho \& Pearson 1960, Lemaire 2002).

The information available on $D$. dolosa refers to the morphology of adults (Lemaire 2002), its geographic distribution (Biezanko 1986, Lemaire 2002), host plant and periods of occurrence (Specht et al. 2005b, 2008). This study complements the previous ones by describing peculiarities of its biology, including the morphology of the immature stages. It also will contribute to a major research project on the several aspects of Hemileucinae (e.g. Specht et al. 2006, 2007, 2008, 2009, 2010, 2011).

\section{Materials and Methods}

The insects were obtained from an oviposition collected on a plantain leaf [Platanus acerifolia (Ailton) Willd. - Platanaceae] and from two aggregations collected on capororoca (Myrsine umbellata Mart. - Myrsinaceae). Behavioral aspects of another last instar aggregation were observed in the field. All specimens came from the Campus Universitário da Região dos Vinhedos (CARVI) of the Universidade de Caxias do Sul (UCS), in Bento Gonçalves, Rio Grande do Sul, Brazil.

Specimens were reared in an acclimatized room $\left(25 \pm 1{ }^{\circ} \mathrm{C}\right.$, $70 \pm 10 \% \mathrm{RH}$ and a 14 hours photo phase). The ecloding larvae were fed with plantain, but survived only until the third instar, indicating that it is not a viable host plant. The remaining larvae, from aggregations collected on capororoca, were kept in screened cages and fed with leaves from the plant itself. The first aggregation (\#1) consisted of 17 fourth instar larvae collected on the trunk of an adult plant located in a sunny place along the campus access road, quite different from the second aggregation (\#2) with 34 third instar individuals which were found on a young plant, approximately 25 meters inside a forest, predominated by araucarias.

Ethological observations were made in the field for an entire day before the collection of aggregations (\#1 and \#2), and during all cage maintenance activities (8:00-10:00 AM). Photographs were obtained both in the field and in the laboratory (Figures 1-2). Voucher specimens were preserved for all developmental stages except the egg. The larvae and pupae were preserved in $70 \%$ ethyl alcohol and deposited in the laboratory collection. The description of morphological features was based on digital images of living specimens, comparing with the morphology and chaetotaxy from the literature (Dias 1978, 1988, Stehr 1987, Lemaire 2002). The measurements were obtained using a digital caliper and a balance, to the nearest one hundredth of a gram.

The duration of the pupal stage was calculated, in days, for the individuals from the two aggregations, whose data were then analyzed using descriptive statistics to calculate the mean values and their respective standard deviations. The means were compared using a " $t$ " test, assuming unequal variances, to the significance level of $95 \%$.

Monthly collections were made within the CARVI from January to December 2006, four nights during each new moon, using light traps as described in Specht et al. (2005a), in order to obtain data on the period of adult occurrence.

\section{Results}

\section{Egg phase}

Eggs (Figure 1a,b) relatively large, mean diameter $1.573 \pm 0.034 \mathrm{~mm}$, height $1.634 \pm 0.089 \mathrm{~mm}(\mathrm{n}=20)$. Color white, shape oval with a flattened micropylar area. Soon after oviposition, the micropyle has a light green transparent color, becoming progressively darker until larval eclosion. In both the oviposition collected in the field, as those obtained in the laboratory, the eggs were arranged in irregular masses.

\section{Larval phase}

The larvae of $D$. dolosa are urticating and developed through six larval instars.

First instar (Figure 1c). Head capsule rounded and black. Integument grayish black with perpendicular red and white striations. Spiracles white ellipsoid, surrounded by a characteristic peritreme, which consists of a projection of the integument itself; reddish colored scoli, becoming proportionately shorter and clearer as they develop. Thoracic legs and prolegs reddish.

Second instar (Figure 1d). Head capsule black with reddish mandibular region. Integument variable in color, with black background, filled with orange spots throughout the entire body. Base of the scoli always surrounded by orange color. Thoracic legs and prolegs red.

Third instar (Figure 1e). Head capsule as in the previous instar. Integument: blackened background more widespread throughout the body, mixed with orange, except on ventral region. In most specimens, orange coverage of second instar fainter, with yellowish tone, scoli and appendages have the same color. Black striations become increasingly more evident, yellow becomes dark brown and scoli light brown.

Fourth instar (Figure 1f). Shape and coloration very similar to previous instar, but black striations occupy virtually the entire integument and scoli are not as developed as the larval body.

Fifth instar (Figure 1g). Head capsule, mandibles and integument dark brown, with black striations occupyin the entire integument. Scoli proportionally smaller and light brown. Legs and prolegs reddish-brown.

Sixth (last) instar - (Figure 2a) head capsule oval, width 5-6 mm, reddish-brown without distinctive color pattern. Clypeus subdivided into smaller structures, forming row of rectangles with seven subdivisions, the five central rectangles larger than the two end ones. Preclypeus surface smooth. Epicranial and lateral adfrontal sutures well defined. Well-defined ecdysal line, starting from the epicranial suture, above upper limit of frons, in the direction of the edges of preclypeus. Distal edge of labrum with relatively well defined median depression. Mandibles with smooth edges. Second antennomere twice as large as basal. Short setae of antenna shorter than sensory setae, reaching at most of one third of antennal length. Ocular region with blackened area totally or partially surrounding the stemmata, stemmata 5 and 6 may free. Stemmata 5 in some specimens smaller than the others,. Hypopharyngeal complex with cone-shaped tubular spinner. Total body length 74-84 $\mathrm{mm}$, overall color predominantly black, with reminiscent inconspicuous orange spots and striations 
near the base of the dorsal, sub-dorsal and lateral scoli, just below sub-spiracular line. Thoracic legs reddish-brown; prolegs concolorous from third to sixth uromere; lateral shield of prolegs brown, sole brownish. Hooks 19 to 24, arranged in biordinal uniseries; prolegs of tenth uromere with 24 to 25 hooks.

In the last instar, head capsule with many setae, especially on anterior region. On the stemmatal region, setae S1, located at the same height as stemmata 3, more developed than the others. Only frontal, cephalo-dorsal and anterior pores present. Genal and posterior areas smooth. Scoli hollow, distributed as followed: four pairs (dorsal subdorsal, lateral and ventral) on the three thoracic segments and on the first, second and seventh uromeres; three pairs on uromeres 3-6 (ventral pair absent), one mid-dorsal pair and three more pairs on the eighth and ninth uromeres. Scoli on anal segment and plate lacking. Scoli short and thick, with long and thin bristles arranged in arborescent shape. Both scoli and bristles yellowish, standing out over blackened tegument. Scoli length and total number of bristles gradually decreasing dorso-ventrally, most developed bristle reaching dorsal region. Maximum observed length of prothoracic scoli and respective bristles distribution as follows: dorsal pairs 4 to $6 \mathrm{~mm}, 20$ to 23 bristles; sub-dorsal pairs 3 to $4 \mathrm{~mm} \mathrm{12-14} \mathrm{bristles;} \mathrm{lateral} \mathrm{pairs}$ $3 \mathrm{~mm}, 6$ to 12 bristles and ventral pairs $2 \mathrm{~mm}, 50$ to 10 bristles. Larval integument covered with many tiny setae. Scoli morphologically very differentiated from each another, with dorsal scoli of thorax and of last uromeres much more developed. Anal segment and plate lacking scoli.

With respect to ethological aspects, the larvae exhibit gregarious behavior in the field (Figure 1e-g), moving around their host plant in a single line. They feed at night, seeking refuge during the day grouped together. Until the fifth instar they hide on branches or trunks (Figure 1f,g), and during the sixth and last instar they hide among the leaf litter and grasses, next to its natural host plant (M. umbellata), locally known as "capororoca". Despite the indication of capororoca as the natural host plant, in the collection of the Laboratório de Biologia do CARVI has a male specimen obtained from a larva collected in Bento Gonçalves, on April 27, 2003, by Tolloti, A., in a Guava tree (Psidium guajava Linn - Myrtaceae).

The pre-pupal period is characterized by a decrease in size and dispersion to seek shelter for the preparation of a rudimentary cocoon with litter interspersed with silk threads that will house the pupa.

\section{Pupal phase}

Immediately after metamorphosis the obtect, glabrous and glossy pupae present a soft, yellowish to light brown integument (Figure 2b). The tegument hardens and darkens quickly, and by the third hour the color becomes brown with clearer regions at the articulations (Figure 2c). Beginning on the sixth hour, the pupae become dark brown (Figure 2d-f).

Spiracles of second to eighth uromeres with similar structure and shape as all others. Prothoracic podothecas forming an inverted triangle just below labrum, and converging laterally with margins of mesothoracic podothecas. These begin at the height of the ceratothecas, and end at the compound eyes; whereas metathoracic podothecas begin below margin of the ceratothecas, and end approximately half way down their total length. Ceratothecas surrounding almost the entire upper region of pupa, forming a semicircle on ventral side of thoracic region. Thoracic and abdominal regions (of $10^{\text {th }}$ uromere) covered with numerous punctures. First three uromeres divided into three distinct parts, consisting of anterior band with numerous longitudinal grooves, median band full of punctures, and the other posterior band with longitudinal grooves, similar to the first band. The second band on fourth, fifht and sixth uromeres, with longitudinal grooves is replaced with bands that form rings encircling the entire pupa, bands quite distinct from the rest of integument due to its light brown color. Although these structures have a smooth appearance when viewed with the naked eye, under a stereomicroscope one can observe narrow transverse micro grooves along the entire length. On seventh uromere, by contrast, posterior reddish band substituted with margins bearing peculiar perpendicular projections that replace the anterior band on eighth uromere. Ninth uromere simpler in structure, consisting of a transverse band surrounding the genital region, and punctures only on median region. In some females, ninth uromere with posterior band similar to the one on seventh uromere. Cremaster not well developed, but equipped with small hooks, which may be absent in some males.

The pupal period of males and females in the same aggregation did not differ. However, the pupal period for individuals of aggregation (1) lasted approximately six months, which was practically four times longer than the individuals of aggregation (2) (Table 1).The individuals of the same sex were always significantly larger in aggregation (1), which went into diapause, different from individuals of aggregation (2). Other morphological features of the pupa (weight, length and width) indicated the occurrence of sexual dimorphism with larger females (Table 1).

\section{Adult phase}

As in the pupae, wingspan of adult females was significantly larger (Figure $2 \mathrm{~g}, \mathrm{~h}$ ), for specimens reared in the laboratory (Table 1) or collected in the wild (Table 2).

Considering the data collected from January to December 2006 (Figure 3), adults were more abundant in early summer and late winter, indicating two emergence peaks. The average wingspan of individuals collected during the winter was higher than that of adults collected at the beginning of summer. This difference was statistically significance in males (Table 2).

\section{Discussion}

The eggs of $D$. dolosa are comparatively large, spherical or ovoid, white and have a large micropylar area, arranged in regular columns or groups, similar to those of several other representatives of the genus (Lemaire 2002, Specht et al. 2008). However, D. dolosa can be distinguished by its flattened micropylar area.

Table 1. Dirphia dolosa: Means and Standard Deviations of mass (g), length and width ( $\mathrm{mm}$ ) and duration (days) of pupae and wingspan ( $\mathrm{mm})$ of the adults from two aggregations collected on capororoca trees (Myrsine umbellata), in Bento Gonçalves municipality, Rio Grande do Sul State, Brazil.

\begin{tabular}{cccc}
\hline Aggregation & Atributos & Females & Males \\
\hline & $\mathrm{N}$ & 5 & 9 \\
Weight & $2.771 \pm 0.050^{\mathrm{Aa}}$ & $2.242 \pm 0.064^{\mathrm{Ba}}$ \\
& Length & $34.230 \pm 0.240^{\mathrm{Aa}}$ & $32.111 \pm 0.268^{\mathrm{Ba}}$ \\
& Width & $12.658 \pm 0.036^{\mathrm{Aa}}$ & $11.931 \pm 0.131^{\mathrm{Ba}}$ \\
& Duration & $205.667 \pm 3.283^{\mathrm{Aa}}$ & $209.500 \pm 5.631^{\mathrm{Aa}}$ \\
& Wingspan & $97.680 \pm 2.407^{\mathrm{Aa}}$ & $80.438 \pm 0.549^{\mathrm{Ba}}$ \\
& & 14 & 12 \\
& Weight & $2.355 \pm 0.037^{\mathrm{Ab}}$ & $1.986 \pm 0.049^{\mathrm{Bb}}$ \\
& Length & $32.899 \pm 0.287^{\mathrm{Ab}}$ & $30.903 \pm 0.327^{\mathrm{Bb}}$ \\
& Width & $11.820 \pm 0.081^{\mathrm{Ab}}$ & $11.198 \pm 0.099^{\mathrm{Bb}}$ \\
& Duration & $55.571 \pm 1.478^{\mathrm{Ab}}$ & $56.857 \pm 1.932^{\mathrm{Ab}}$ \\
& Wingspan & $79.370 \pm 2.102^{\mathrm{Ab}}$ & $72.012 \pm 0.727^{\mathrm{Bb}}$ \\
\hline
\end{tabular}

Means were compared by t test assuming unequal variances at $95 \%$ of confidence level. Capital letters indicate distinct differences between sexes in each row; lowercase letters indicate differences between aggregations. 

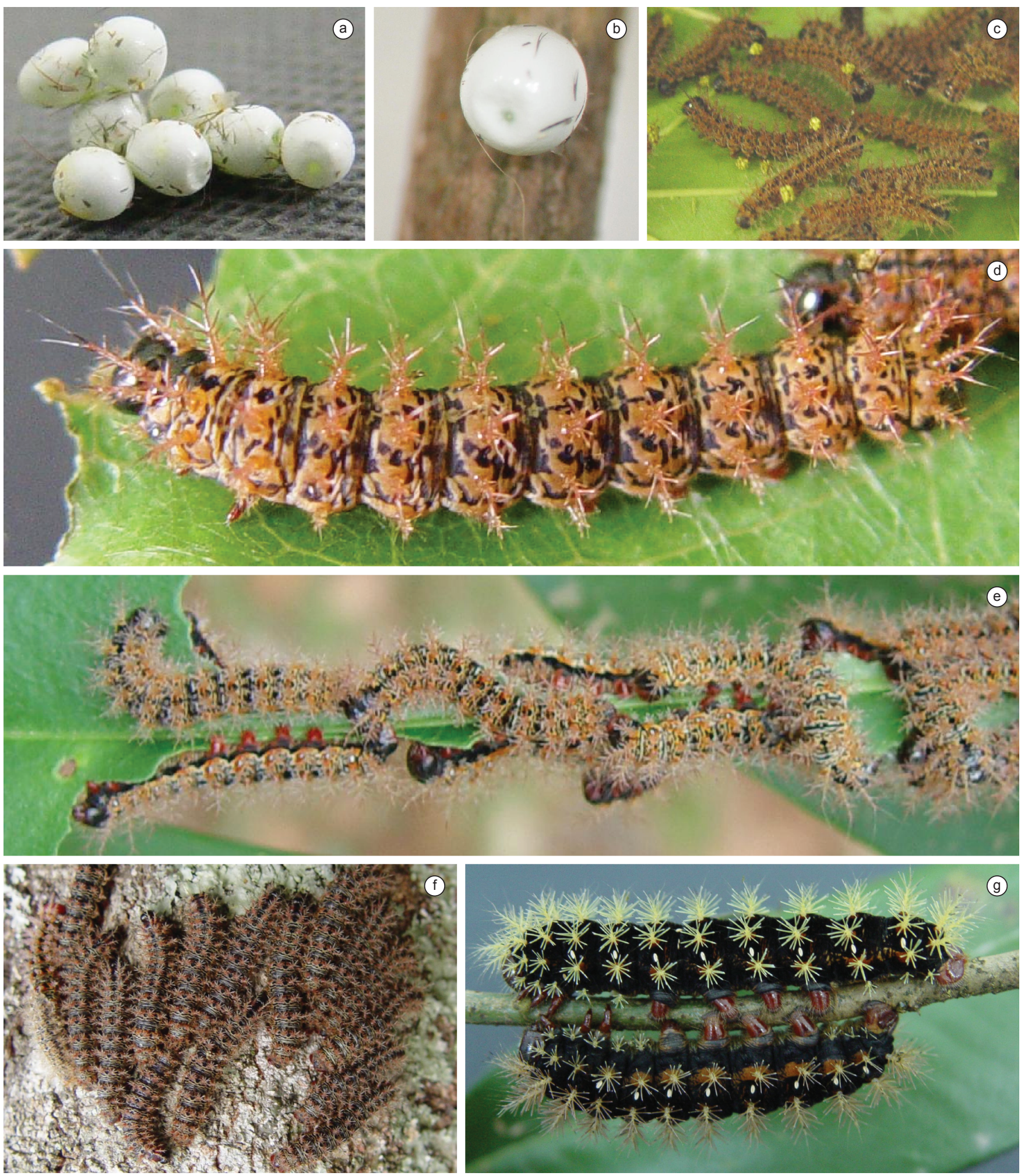

Figure 1. Dirphia dolosa: a) egg cluster; b) egg: micropilar area; c) first instar larvae; d) second instar larvae; e) third instar larvae; f) fourth instar larvae; g) fifth instar larvae.

Several larval characteristics of $D$. dolos $a$, such as urtication and occurrence of six instars, are shared by other congenerics, such as $D$. araucariae Jones, 1908 (Borges 1986), D. moderata Bouvier, 1919 (Zanuncio et al. 1994, Pereira et al. 2008) and by other genera, such as Automeris Hübner, [1819] (Specht et al. 2006, 2007), Leucanella
Lemaire, 1969 (Specht et al. 2009), Molippa Walker, 1855 (Bourquin 1949, Specht et al. 2010) and Periga Walker, 1855 (Specht et al. 2011).

The last instar larvae, resemble those of another hemileucid, Leucanella viridescens (Walker, 1855) (Specht et al. 2009), distinguished from it by the reddish-brown prolegs, slightly more 

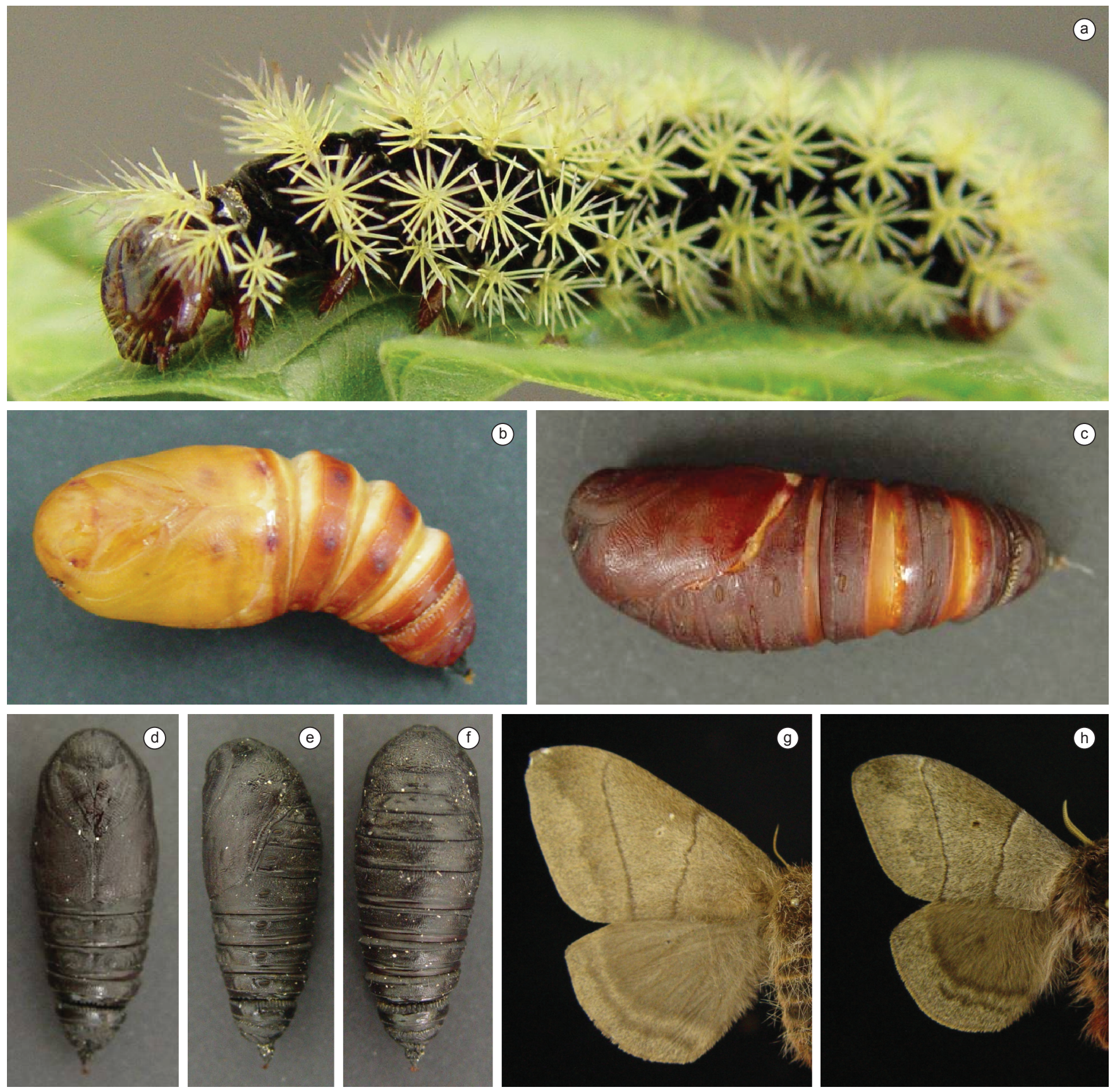

Figure 2. Dirphia dolosa: a) sixth instar larvae; b) pupa immediately after metamorphose; c) pupa three hours after metamorphose; d) pupa on ventral view; e) pupa on lateral view; f) pupa on dorsal view; g) female on dorsal view; h) male on dorsal view.

Table 2. Dirphia dolosa: Wingspan means ( $\mathrm{mm}$ ) and standard deviations of females and males, collected with light trap (four monthly collections), in summer (January to March) and in winter (June to August) of 2006, in Bento Gonçalves municipality, Rio Grande do Sul State, Brazil.

\begin{tabular}{|c|c|c|c|c|c|c|c|}
\hline & \multicolumn{3}{|c|}{ Summer } & \multicolumn{3}{|c|}{ Winter } & \multirow{2}{*}{ Sig. } \\
\hline & $\mathbf{N}$ & Wingspan & Range & $\mathbf{N}$ & Wingspan & Range & \\
\hline Females & 15 & $81.750 \pm 5.170$ & $70-89$ & 12 & $88.688 \pm 8.380$ & 71-105 & ns \\
\hline Males & 45 & $75.244 \pm 3.944$ & $68-81$ & 44 & $78.136 \pm 4.638$ & $70-85$ & $*$ \\
\hline Sig. & & * & & & $*$ & & \\
\hline
\end{tabular}

Means were compared by $\mathrm{t}$ test assuming unequal variances at $95 \%$ of confidence. Significance: $\mathrm{ns}$ - not significant, ${ }^{*}$ significant at $0.05 \%$. 
Specht, A. et al.

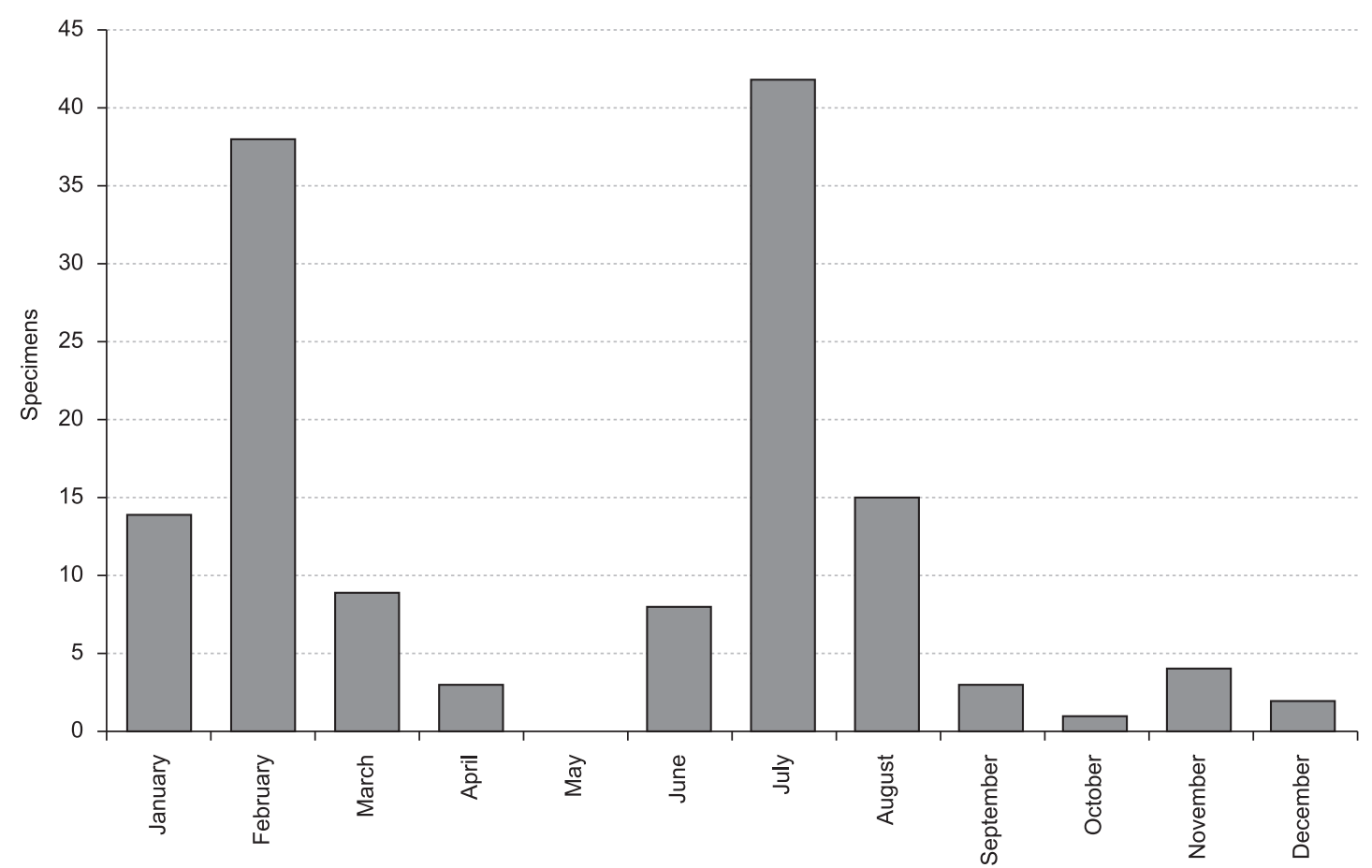

Figure 3. Dirphia dolosa: Number of adults collected in light traps, in four nights by month, in Bento Gonçalves municipality, Rio Grande do Sul State, Brazil, from January to December 2006.

arborescent scoli and the presence of the inconspicuous orange colored stripes in the lateral-ventral region and by the integument having many setae as described for Hylesia nigricans (Berg, 1875) (Saturniidae: Hemileucinae) (Isacovich 1970).

The highly differentiated scoli are similar to those described for most hemileucids. However, their absence in the anal segment and plate differs from the basic distribution pattern described for the subfamily (Lemaire 2002).

Within the head capsule, the region of the clypeus, subdivided into seven rectangles resembling that seen in Lonomia obliqua Walker, 1855 (Saturniidae: Hemileucinae) (Lorini \& Corseuil 2001), stands out. However, in D. dolosa, the five central rectangles are larger when compared to the two triangles in the extremities, while in L. obliqua all the rectangles have a similar size.

The gregarious behavior, walking in single file, nocturnal feeding and larval grouping is relatively common and a characteristic among the Hemileucinae representatives (Lemaire 2002).

Although $D$. dolosa feeds mainly on its natural host plant capororoca (Specht et al. 2005a, 2008), it can also be found feeding and developing on introduced plants from other botanic families such as the guava tree. Similar behavior is described by Lemaire (2002) who lists several species of Dirphia reared on exotic host plants.

Also in relation to feeding habits, it is important to note that several representatives of Dirphia, whose natural host plants are known, feed on Myrsinaceae. Among them are some species known to be polyphagous: D. avia Stoll, 1780 (Silva et al. 1968, Janzen \& Hallwachs 2009), D. horcana Schaus, 1911 (Janzen \& Hallwachs 2009), D. moderata (Dias 1988, Zanuncio et al. 1994, Pereira et al. 2008); or oligophagous, with larvae found feeding exclusively on Myrsinaceae such as D. baroma (Schaus, 1906) (Specht et al. 2008) and Dirphia monticola Zerny, 1924 (Zikán, 1927). Besides these, Callodirphia arpi (Schaus, 1908), whose larvae also only feed on Myrsinaceae (Zikán 1927), is worth mentioning.
Considering the feeding specificity of these species and the inclusion of D. monticola in "Critically endangered" category of the Brazilian fauna threatened with extinction list (Machado et al. 2008), Myrsinaceae stands out as a plant group of extreme importance for the conservation of Lepidoptera and should be prioritized in future studies of biodiversity.

The pupae of $D$. dolosa structurally resemble those of many hemileucids (Lemaire 2002, Specht et al. 2008). Instead of being rough like those of most species, they are similar to those of D. avia, D. panamensis (Schaus, 1921), D. somniculosa (Cramer, 1777) (Lemaire 2002) and D. baroma (Specht et al. 2008) which appear glossy rather than wrinkled like those of D. araucariae (Specht et al. 2008) or D. moderata (Dias 1988).

The not well developed hooks of the cremaster, which may be absent in some males of $D$. dolosa, also contrasts with the majority of the species of the genus. Lemaire (2002) indicates that most Dirphia species have a cremaster with hooks. However, he describes D. somniculosa pupae as not having a cremaster (or hooks), without indicating whether this occurs in both sexes or only in males.

The loss of the cremaster, or at least the hooks, also occurs in D. baroma (Specht et al. 2008) and in other hemileucids which pupate in the soil, such as $P$. circumstans (Specht et al. 2008, 2011) and L. obliqua (Lorini \& Corseuil 2001, Lorini 2008), and certainly represents an adaptation to the formation of the pupa in the soil, without the protection of a resistant cocoon. More detailed behavioral studies on male and female pupae of $D$. dolosa should be carried out to assess possible differences related to the presence and absence of hooks on the cremaster for each sex.

The big difference between the duration of the pupal phase among aggregations (Table 1) indicates that this species has a facultative pupal diapause, alike other hemileucinids, such as Automeris coresus (Boisduval, 1859) (Bourquin 1944), A. io (Fabricius, 1775) (Lemaire 2002), A. illustris (Walker, 1855) (Specht et al. 2006) and A. naranja Schaus, 1898 (Mabilde 1896, D’Almeida 1944, Gardiner 1958, 
Specht et al. 2007). The observation that individuals of the same sex were always significantly larger in aggregation (1), which underwent diapause, with respect to individuals from aggregation (2) (Table 1), deserves special attention. Liu et al. (2007) demonstrated that in Helicoverpa armigera (Hübner, [1809]) (Lepidoptera: Noctuidae) the pupal diapause has a high energy cost which determines that the diapausing individuals have to accumulate additional energy reserves in order to avoid unfavorable environmental conditions. Additionally, Liu et al. (2010) demonstrated that the better quality of the host plant significantly influences the weight of the pupae and the number of individuals entering pupal diapause. Thus, in the present study, nutritional issues may be involved. For example, the host plant at the edge of the forest, can be larger (adult) and have a better location for photosynthesis, and may have offered better quality food for the larvae of aggregation (1) than the younger plant that contained aggregation (2), which was in the shadows all the time.

The sexual dimorphism observed in the pupae and adults of this species (Table 1) is very typical among the representatives of Hemileucinae (Lemaire 2002) and has been documented for representatives of Dirphia, such as D. araucariae (Borges 1985, Borges et al. 1986) and D. moderata (Zanuncio et al. 1994).

Despite adults being collected in almost all the seasons of the year, Dirphia dolosa presents two generations per year in Rio Grande do Sul, similar to other hemileucids such as D. araucariae (Borges \& Macedo 1986), A. illustris (Specht et al. 2006) and A. naranja (Specht et al. 2007). The comparison of the average wingspan of moths collected in winter and summer (Table 2) indicated that, analogous to that described by Liu et al. (2010) for H. armigera, the adults of $D$. dolosa collected during the winter, presumably diapausers, are larger than those collected during the summer, presumably non-diapausers.

Similarly to what has been presented in other groups of Lepidoptera (eg Freitas \& Brown Junior 2005) and for representatives of Hemileucinae (Specht et al. 2010), the study of D. dolosa, revealed characteristics different from those found in other representatives of the genus. The various parameters of all the developmental stages provide morphological and biological peculiarities that can be used in the taxonomy of the group and contribute to conservation studies of the taxon itself, of similar species and of the biome itself.

\section{References}

BIEZANKO, C.M. 1986. Adelocephalidae, Saturniidae, Mimallonidae, Lasiocampidae, Eupterotidae e Lymantriidae da Região Missioneira do Rio Grande do Sul. Rev. Cent. Cienc. Rurais 16(2):89-112.

BORGES, J.D. 1985. Biologia de Dirphia araucariae em laboratório. Pesq. agropec. Bras. 20(2):155-158.

BORGES, J.D. 1986. Influência da temperatura no desenvolvimento de Dirphia araucariae. Pesq. Agropec. Bras. 21(6):587-592.

BORGES, J.D. \& MACEDO, J.H.P. 1986. Ocorrência de Dirphia araucariae em Araucaria angustifolia no município de Congonhinhas, PR. Pesq. Agropec. Bras. 21(2):101-104.

BORGES, J.D., CARNEIRO, M.F. \& ALMEIDA, A.A. 1986. Dados sobre as pupas e comportamento dos adultos de Dirphia araucariae. Pesq. Agropec. Bras. 21(5):467-471.

BOURQUIN, F. 1944. Observaciones sobre Automeris coresus (Boisduval) 1859 - Lep. Fam. Hemileucinae. In Mariposas Argentinas - vida, desarrollo, costumbres \& hechos curiosos de algunos lepidópteros argentinos. (F. Bourquin, ed.). Buenos Aires, Ferrari Hermanos Bartolome Mitre, p.33-35.

BOURQUIN, F. 1949. Metamorfosis de Molippa sabina (Walker) (Lep. Hemileucidae). Rev. Soc. Ent. Arg. 14(4):204-210.

D'ALMEIDA, R.F. 1944. Estudos biológicos sobre Lepidopteros - Automeris aurantiaca Weymer, 1907. Arq. Zool. 4:33-72.
DIAS, M.M. 1978. Morfologia e Biologia de Citheronia laocoon (Cramer, 1777) (Lepidoptera, Adelocephalidae). Rev. bras. Ent. 22(3-4):167-197.

DIAS, M.M. 1988. Estágios imaturos de Dirphia (Dirphia) moderata Bouvier, 1929 (Lepidoptera, Saturniidae). Rev. bras. Ent. 32(2):273-278.

FREITAS, A.V.L. \& BROWN JUNIOR, K.S. 2005. Immature stages of Napeogenes sulphurina Bates, 1862 (Lepidoptera, Nymphalidae, Ithomiinae) from Northeastern Brazil. J. Lep. Soc. 59(1):35-37.

GARDINER, B.O.C. 1958. Rearing Automeris aurantiaca Weymer. Bull. Amat. Ent. Soc. 17:14-15.

ISACOVICH, M.C.B. 1970. Descripción de estados inmaturos y biología de Hylesia nigricans (Berg). Idia (Supl. Forestal) 6:46-72.

JANZEN, D.H. \& HALLWACHS, W. 2009. Dynamic database for an inventory of the macrocaterpillar fauna, and its food plants and parasitoids, of Area de Conservacion Guanacaste (ACG), northwestern Costa Rica (nn-SRNP-nnnnn voucher codes). http://janzen.sas.upenn.edu.

LEMAIRE, C. 2002. The Saturniidae of America, v. 3: Hemileucinae. Goecke \& Evers, Keltern, 1388p.

LIU, Z., GONG, P., WU, K.J, WEI, W., SUN, J.H. \& LI, D.M. 2007. Effects of larval host plants on over-wintering preparedness and survival of the cotton bollworm Helicoverpa armigera (Hübner) (Lepidoptera: Noctuidae). J. Insect Physiol. 53:1016-1026. PMid:17597144. http:/ dx.doi.org/10.1016/j.jinsphys.2007.05.005

LIU, Z., GONG, P., LI, D. \& WEI, W. 2010. Pupal diapause of Helicoverpa armigera (Hübner) (Lepidoptera: Noctuidae) mediated by larval host plants: pupal weight is important. J. Insect Physiol. 56:1863-1870. PMid:20709070. http://dx.doi.org/10.1016/j.jinsphys.2010.08.007

LORINI, L.M. 2008. 7 - Saturniidae, Hemileucinae - Lonomia obliqua Walker, 1855. In Lepidópteros de Importância Médica - Principais espécies no Rio Grande do Sul (A. Specht, E. Corseuil \& H.B. Abella, org.). USEB, Pelotas, p.165-185.

LORINI, L.M. \& CORSEUIL, E. 2001. Aspectos morfológicos de Lonomia obliqua Walker (Lepidóptera: Saturniidae). Neotrop. Entomol 30:373-378.

MABILDE, A.P. 1896. Guia práctico para os principiantes collecionadores de insectos, contendo a descrição fiel de perto de 1000 borboletas com 180 figuras lytographadas em tamanho, formas e desenhos conforme o natural. Estudo sobre a vida de insectos do Rio Grande do Sul e sobre a caça, classificação e conservação de uma coleção mais ou menos regular. Porto Alegre, Gunlach \& Schuldt, 238p.

MACHADO, A.B.M., DRUMMOND, G.M. \& PAGLIA, A.P. 2008. Livro vermelho da fauna brasileira ameaçada de extinção. MMA, Brasília; Fundação Biodiversitas, Belo Horizonte, 2v., 1420 p.

MIELKE, C.G.C. \& MOSER, A. 2007. Dirphia Hübner (Lepidoptera, Saturniidae, Hemileucinae): Descrição de uma espécie nova do Sul do Brasil e da Fêmea de D. rufescens F. Johnson \& Michener. Rev. Bras Zool. 24:319-322. http://dx.doi.org/10.1590/S0101-81752007000200008

OITICICA FILHO, J. \& PEARSON, H.R. 1960. Sobre o tipo de Dirphia ursina Walker, 1855 (Lepidoptera, Hemileucinae). Bol. Mus. Nac. Nov. Sér. Zool. 221:1-19.

PEREIRA, F.F., ZANUNCIO, A.J.V., FELIPE, J.P.M., LORENZON, A.S. \& CANEVARI, G.C. 2008. Desenvolvimento e reprodução de Dirphia moderata (Lepidoptera: Satutniidae) em Eucalyptus cloeziana e Psidium guajava em laboratório. Rev. Árvore 32(6):1119-1124.

SILVA, A.G.A., GONÇALVES, C.R., GALVÃO, D.M., GONÇALVES, A.J.L., GOMES, J., SILVA, M.N. \& SIMONI, L. 1968. Quarto catálogo dos insetos que vivem nas plantas do Brasil: seus parasitos e predadores. Ministério da Agricultura, Rio de Janeiro, 622p.

SPECHT, A., TESTON, J.A., DI MARE, R.A. \& CORSEUIL, E. 2005a. Noctuídeos (Lepidoptera, Noctuidae) coletados em quatro Áreas Estaduais de Conservação do Rio Grande do Sul, Brasil. Rev. Bras. Entomol. 49(1):130-140. http://dx.doi.org/10.1590/S008556262005000100015

SPECHT, A., FORMENTINI, A.C. \& CORSEUIL, E. 2005b. Lepidópteros de Importância Médica ocorrentes no Rio Grande do Sul. III. Saturniidae, Hemileucinae. Biociências 13(2):149-162. 
SPECHT, A., FORMENTINI, A.C. \& CORSEUIL, E. 2006. Biologia de Automeris illustris (Walker) (Lepidoptera, Saturniidae, Hemileucinae). Rev. Bras. Zool. 23(2):537-546. http://dx.doi.org/10.1590/S010181752006000200029

SPECHT, A., FORMENTINI, A.C. \& CORSEUIL, E. 2007. Biologia e aspectos morfológicos dos estágios imaturos de Automeris naranja Schaus (Lepidoptera, Saturniidae, Hemileucinae). Rev. Bras. Zool. 24(3):523-534. http://dx.doi.org/10.1590/S0101-81752007000300001

SPECHT, A., CORSEUIL, E. \& FORMENTINI, A.C. 2008. 5 - Saturniidae, Hemileucinae. In Lepidópteros de Importância Médica - Principais espécies no Rio Grande do Sul (A. Specht, E. Corseuil \& H.B. Abella, org.). USEB, Pelotas, p.81-131.

SPeCht, A., CORSEuil, E., Benedetti, A.J., POletto, G. \& FORMENTINI, A.C. 2009. Aspectos biológicos e morfológicos de Leucanella viridescens (Lepidoptera: Saturniidae: Hemileucinae). Zoologia 26(1):25-31. http://dx.doi.org/10.1590/S198446702009000100005
SPECHT, A., FORMENTINI, A.C. \& BENEDETTI, A.J. 2010. Biology and morphology of Molippa cruenta (Lepidoptera: Saturniidae) in the laboratory. Zoologia 27(3):347-352. http://dx.doi.org/10.1590/S198446702010000300005

SPECHT, A., LORINI, L.M., FRONZA, E. \& POLETTO, G. 2011. Biological aspects of Periga circumstans Walker, 1855 (Lepidoptera: Saturniidae: Hemileucinae) with larvae reared on khaki and Paraguay tea leaves. Braz. J. Biol. 71(4):1015-1022. http://dx.doi.org/10.1590/S151969842011000500022

STEHR, F.W. 1987. Order Lepidoptera. In Immature Insects (F.W. Stehr, ed.). Kendall/Hunt, Iowa, v.2, p.288-596.

ZANUNCIO, T.V., ZANUNCIO, J.C., MEIRA, I.A. \& ARAÚJO, F.S. 1994. Caracterização das fases larval e adulta de Dirphia avicula (Lepidoptera: Saturniidae) em folhas de Eucalyptus urophylla. Rev. Árvore 18(2):153-158.

ZIKÁN, J.F. 1927. Biologie der Heliconisa-Arten (Lep. Saturnid.). Deut. Ent. Zeitsch. 1927:58-82. 